\title{
Artikel
}

\section{Noodweer bij eenvoudige mishandeling: vrijspraak of OVAR?}

Niet de kwalificatie 'mishandeling', maar het ten laste gelegde gedrag van de verdachte moet bewezen worden. Eenheid van rechtstoepassing is dringend gewenst.

Mr. P.C. (Perry) Quak*

\section{NTS 2020/6}

\section{Inleiding}

In strafzaken waarbij 'eenvoudige mishandeling' (art. 300 van het Wetboek van Strafrecht, verder: Sr) is ten laste gelegd, leidt een geslaagd beroep op noodweer nogal eens tot verschillende uitkomsten, te weten tot ontslag van alle rechtsvervolging of tot vrijspraak. ${ }^{1}$ Dit ogenschijnlijk futiele verschil - in beide gevallen wordt immers geen straf opgelegd - kan door de betrokken burgers en de samenleving als geheel echter wél ${ }^{2}$ als een belangrijk verschil worden ervaren. Een dergelijke verschillende toepassing van het recht werkt onbegrip voor de strafrechtspleging in de hand, en dat doet afbreuk aan het gezag van de strafrechter. Eenheid van rechtstoepassing is daarom gewenst.

Mr. P.C. Quak is senior rechter in de Rechtbank Gelderland.

1. Recentelijk bijv. de Militaire Kamer in Hof Arnhem-Leeuwarden 25 juli 2019, ECLI:NL:GHARL:2019:6152; idem bijv. Hof Amsterdam 1 mei 2018, ECLI:NL:GHAMS:2018:1543 en ook A-G Hofstee in Concl. 13 november 2018, ECLI:NL:PHR:2018:1231, punt 16 (gevolgd door HR 4 december 2018).

2. Anders dan bijvoorbeeld A-G Vegter suggereert in zijn conclusie bij HR 12 mei 2015, ECLI:NL:HR:2015:1237 (Concl. A-G Vegter 10 maart 2015, ECLI:NL:PHR:2015:585, punt 13).
In deze bijdrage gaat het niet om de vraag of wel of niet terecht noodweer wordt aangenomen, maar wel om de vraag tot welke einduitspraak de strafrechter, bij een geslaagd beroep op noodweer bij 'eenvoudige mishandeling', moet komen volgens het schema van artikel 352 van het Wetboek van Strafvordering (verder: Sv). Moet dat zijn: vrijspraak van het ten laste gelegde feit (art. 352 lid $1 \mathrm{~Sv}$ ) of ontslag van alle rechtsvervolging (art. 352., lid $2 \mathrm{~Sv})$ ?

\section{Schema artikelen 350 en 352 van het Wetboek van Strafvordering}

Het beslismodel voor de strafrechter is algemeen bekend: de vragen van artikel $350 \mathrm{~Sv}$ leiden tot beantwoording volgens het schema van artikel $352 \mathrm{~Sv}$. Dat betekent dat de strafrechter allereerst de vraag moet beantwoorden of het feitencomplex, zoals ten laste gelegd, als bewezen kan worden aangenomen. Als de strafrechter niet bewezen acht dat de verdachte het ten laste gelegde feit heeft begaan, dient vrijspraak te volgen (art. 352 lid $1 \mathrm{~Sv}$ ). Als de strafrechter wel bewezen acht dat de verdachte het ten laste gelegde feit heeft begaan, dient de strafrechter te beoordelen welk strafbaar feit, volgens een wettelijke delictsomschrijving, het bewezenverklaarde oplevert (de kwalificatie; art. $350 \mathrm{~Sv}$ ). Als de strafrechter vervolgens een strafuitsluitingsgrond aan- 
wezig acht (zoals noodweer) en derhalve het bewezen verklaarde feit niet kan kwalificeren als strafbaar feit of als de verdachte niet strafbaar wordt geacht, dient de verdachte te worden ontslagen van alle rechtsvervolging ten aanzien van dat feit (art. 352 lid $2 \mathrm{~Sv}$ ).

Tot zover is dit schema even simpel als overzichtelijk. Voor zover mij bekend wordt dit schema ook steevast op de voorgeschreven wijze toegepast door de strafrechter, behalve bij 'eenvoudige mishandeling'. En let wel, bij (poging tot) zware mishandeling komt een dergelijk verschil in toepassing van het schema van art. 350/352 $\mathrm{Sv}$ evenmin voor. Hoe kan het dan toch dat er in de jurisprudentie wel verschillende uitkomsten zijn als het gaat om tenlastelegging van 'eenvoudige mishandeling'?

\section{Tenlastelegging zonder werkwoord 'mishandelen' verdient de voorkeur}

Dat heeft alles te maken met de gebruikelijke redactie van de tenlastelegging door het Openbaar Ministerie. De strafrechter is immers gebonden aan de tenlastelegging; de tekst daarvan is allesbepalend. En het Openbaar Ministerie hanteert in de tekstblokken voor 'eenvoudige mishandeling' een standaardredactie, die doorgaans ${ }^{3}$ de volgende beschuldigende tekst bevat: ${ }^{4}$

'dat verdachte opzettelijk een persoon, te weten $\mathrm{X}$, heeft mishandeld door die $\mathrm{X}$ tegen het lichaam te schoppen en/of te slaan en/of aan de haren te trekken en/of te steken met een scherp voorwerp'.

Het gaat hier om het woord 'mishandeld'. Omdat in de gebruikelijke redactie van bijvoorbeeld (poging tot) zware mishandeling niet het werkwoord mishandelen (in welke vervoeging dan ook) voorkomt, leidt een geslaagd beroep op noodweer bij zware mishandeling zonder uitzondering tot ontslag van alle rechtsvervolging. Gek genoeg is dat dus anders bij 'eenvoudige mishandeling'.

De gedachte achter een vrijspraak na een geslaagd beroep op noodweer bij 'eenvoudige mishandeling' is, dat de woorden 'heeft mishandeld' niet kunnen worden bewezen. Het idee hierachter is weer dat uit de jurisprudentie voortvloeit dat het begrip 'mishandelen' mede omvat een 'ingeblikte wederrechtelijkheid', terwijl die ingeblikte wederrechtelijkheid wordt opgeheven door het bestaan van een rechtvaardigingsgrond, namelijk noodweer. ${ }^{5}$ De redenering gaat dan als volgt verder: door het ontbreken van de ingeblikte wederrechtelijkheid kan niet meer worden gesproken van 'mishande-

3. Soms wordt ook de redactie gebruikt dat verdachte 'opzettelijk mishandelend' $X$ heeft geslagen etc.

4. Tekst iets bewerkt ten behoeve van de leesbaarheid van deze bijdrage, o.m. door weglating van tijd en plaats.

5. J.S. Nan, 'Ingeblikte wederrechtelijkheid bij mishandeling', TPWS 2014/10, p. 52 ling', zodat vrijspraak moet volgen van de woorden 'heeft mishandeld'.

De cirkel is rond, maar het komt nogal theoretisch, zelfs semantisch, over.

Van deze redenering wordt dan ook wel een versimpelde, meer taalkundige variant gehoord: door het handelen uit noodweer was niet langer sprake van een 'misse handeling'; derhalve geen 'mishandeling'. Bij beide redeneringen komt men dan tot dezelfde uitkomst: vrijspraak, omdat (de vervoeging van) het werkwoord 'mishandelen' niet kan worden bewezen.

Voor zover dit een probleem is, en mijn stelling is dat dat uit maatschappelijk oogpunt het geval is, kan het Openbaar Ministerie het heel praktisch oplossen door een slimmere tenlastelegging voor 'eenvoudige mishandeling' te hanteren, namelijk:

'dat verdachte op [datum] te [plaats], opzettelijk een persoon, te weten $\mathrm{X}$,

- meermalen in het gezicht en/of tegen het hoofd heeft gestompt en/of geslagen en/of

- meermalen aan de haren heeft getrokken en/of

- meermalen tegen het hoofd en/of het lichaam heeft geschopt en/of getrapt terwijl $\mathrm{X}$ op de grond lag, waardoor voornoemde $\mathrm{X}$ letsel heeft bekomen en/of pijn heeft ondervonden'. ${ }^{6}$

In dit geval staat het werkwoord 'mishandeld' niet meer in de tenlastelegging, waardoor volgens het genoemde schema van de artikelen 350 en 352 Sv ook in geval van noodweer bij 'eenvoudige mishandeling' gewoon een ontslag van alle rechtsvervolging zal moeten worden uitgesproken en niet: vrijspraak.

\section{Het is niet de kwalificatie die moet worden bewezen}

Als het Openbaar Ministerie deze eenvoudige aanpassing in de tekstblokken echter niet zou doorvoeren, zie ik ook een juridisch argument waarom de strafrechter in geval van noodweer bij 'eenvoudige mishandeling' (gewoon) een ontslag van alle rechtsvervolging zal moeten uitspreken.

De basis voor het idee van ingeblikte wederrechtelijkheid bij mishandeling wordt gevonden in een aantal arresten van de Hoge Raad. ${ }^{7}$ De Hoge Raad overweegt in zijn jurisprudentie over mishandeling namelijk bij

6. Conform de tenlastelegging zoals aan de orde was in de strafzaak die heeft geleid tot het arrest van de Hoge Raad van 12 mei 2015, ECLI:NL:HR:2015:1237, RvdW 2015/656; zie r.o. 2.2.1. Aan deze wijze van tenlastelegging heeft de Hoge Raad zijn zegen gegeven.

7. Ik volsta hier met vermelding van drie arresten: HR 5 juli 2011, ECLI:NL:HR:2011:BQ6690, NJ 2011/466 (met name r.o. 2.3.1), HR 9 september 2014, ECLI:NL:HR:2014:2677, NJ 2014/402 , alsmede het al aangehaalde arrest van HR 12 mei 2015, ECLI:NL:HR:2015:1237 (r.o. 2.3) en de Concl. A-G Vegter 10 maart 2015, ECLI:NL:PHR:2015:585. 
wijze van handvat voor de kwalificatie ${ }^{8}$ van 'mishandeling' het volgende:

'Onder "mishandeling" in de zin van art. $300 \mathrm{Sr}$ moet worden verstaan het aan een ander toebrengen van lichamelijk letsel of pijn alsmede - onder omstandigheden - het bij een ander teweegbrengen van een min of meer hevige onlust veroorzakende gewaarwording in of aan het lichaam, een en ander zonder dat daarvoor een rechtvaardigingsgrond bestaat.'

De laatste zinsnede 'zonder dat daarvoor een rechtvaardigingsgrond bestaat' wordt als argument gebruikt voor het bestaan van ingeblikte wederrechtelijkheid. Maar dat is ten onrechte.

Want eigenlijk zegt de Hoge Raad hier niets meer of minder dan dat - indien wel een rechtvaardigingsgrond bestaat - de tweede vraag van artikel $350 \mathrm{~Sv}$ negatief beantwoord moet worden: het bewezenverklaarde levert dan immers geen strafbaar feit volgens de pet op. En dat moet ingevolge artikel 352 lid 2 Sv tot ontslag van alle rechtsvervolging leiden.

De voorstanders van vrijspraak na noodweer bij 'eenvoudige mishandeling' stellen zich dus eigenlijk op het standpunt dat de strafrechter een kwalificatie bewezen moet verklaren en dat lijkt mij niet de bedoeling van het schema van de artikelen 350 en $352 \mathrm{~Sv}$.

Voor zover de voorstanders van vrijspraak na noodweer bij 'eenvoudige mishandeling' vervolgens willen betogen dat het werkwoord 'mishandelen' uitsluitend kwalificatief kan worden gelezen, negeren zij volgens mij dat dit een in het dagelijks spraakgebruik doodnormale uitdrukking is en daardoor zonder meer (ook) feitelijke betekenis heeft.

\section{Maatschappelijk onwenselijke verschillen}

Door uit het oog te verliezen dat aan het werkwoord 'mishandelen' simpelweg vooral feitelijke betekenis toekomt, in elk geval niet louter kwalificatieve betekenis, wordt mijns inziens ook genegeerd dat een gemiddelde burger elke vrijspraak van mishandeling zal opvatten als een vrijspraak van de uitvoeringshandelingen, te weten het slaan, schoppen, haren trekken en/of steken met een scherp voorwerp, et cetera. Maar dat is niet wat de strafrechter doet als hij vrijspreekt wegens een geslaagd beroep op noodweer. In dat geval laat de strafrechter zich zelfs niet meer uit over de pijn, het letsel en de min

Dat de Hoge Raad het hier heeft over de kwalificatie, volgt uit r.o. 2.4 van het arrest van HR 12 mei 2015, ECLI:NL:HR:2015:1237, die begint met de woorden: 'Het middel steunt op de opvatting dat voor de kwalificatie 'mishandeling' is vereist dat in de bewezenverklaring overeenkomstig de tenlastelegging met zoveel woorden tot uitdrukking is gebracht dat het toebrengen van pijn, letsel of onlustgevoelens "mishandelend" of "wederrechtelijk" is geschied.' (cursivering door de auteur) of meer hevige onlust veroorzakende gewaarwording die de verdachte in of aan het lichaam van eerder genoemde $\mathrm{X}$ heeft toegebracht. De gemiddelde burger zal dit niet begrijpen.

Sterker nog, gesteld kan worden dat 'zelfverdediging' pas als noodweer kan worden aangemerkt indien daardoor sprake is van enige vorm van inbreuk op de rechtsbelangen van de aanrander, hiervoor aangeduid als $\mathrm{X}$. Deze inbreuk op de rechtsbelangen van $\mathrm{X}$ impliceert juist wel een vorm van wederrechtelijkheid. En zelfs als het wederrechtelijke karakter van de gedragingen door de verdachte - vervolgens - komt te vervallen wegens een rechtvaardigingsgrond, bijvoorbeeld die van artikel $41 \mathrm{Sr}$, leidt dit via de weg van artikel 352 lid $2 \mathrm{~Sv}$ tot ontslag van alle rechtsvervolging. De techniek van strafvordering is nu eenmaal dominant, zoals A-G Vegter al opmerkte. ${ }^{9}$

Eenheid van strafvorderlijke rechtstoepassing is dus gewenst.

\section{Conclusie}

In de strafrechtpraktijk leidt bij het veel voorkomende misdrijf 'eenvoudige mishandeling' eenzelfde geslaagd beroep op noodweer tot verschillende rechterlijke einduitspraken. Alhoewel bij noodweer een ontslag van alle rechtsvervolging uitgangspunt is, leidt dit bij het misdrijf van artikel $300 \mathrm{Sr}$ ('eenvoudige mishandeling') ook wel tot vrijspraak. De gemiddelde burger zal deze verschillende uitkomsten niet begrijpen. Deze situatie is dan ook maatschappelijk ongewenst.

Het Openbaar Ministerie kan hier op praktische wijze veel, zo niet alles, aan doen door het strafbare feit van artikel $300 \mathrm{Sr}$ voortaan anders ten laste te leggen, en wel met weglating van het werkwoord 'mishandelen' (in welke vervoeging dan ook). Voorbeeld kan dan worden genomen aan de tenlastelegging zoals hiervoor genoemd en die aan de orde was in de strafzaak die heeft geleid tot het aangehaalde arrest van de Hoge Raad van 12 mei 2015 .

De koninklijke weg zou echter zijn dat de Hoge Raad zich hierover alsnog ondubbelzinnig uitspreekt. In dat geval weten praktijkjuristen precies waar ze aan toe zijn. Maar de kans op een normaal cassatieberoep acht ik klein. Immers, de wegens noodweer van 'eenvoudige mishandeling' vrijgesproken verdachte zal daarmee tevreden zijn en dus niet snel in cassatie gaan. En als de advocaat-generaal bij het hof dat ook niet doet, vermoed ik dat cassatie in het belang van de pet nodig zal zijn om op dit punt eenheid van (strafvorderlijke) rechtstoepassing te bereiken. 